\section{IJ§ER}

ISSN: 2149-5939
International Journal of Social Sciences and Education Research

Online, http://dergipark.gov.tr/ijsser

Volume: 3(2), 2017

\title{
The importance of EBIT- EBITDA disclosure in annual reports: A comparison from Turkey
}

\author{
Burcu Adiloğlu1 $\quad$ Bengü Vuran ${ }^{2}$
}

Received Date: $01 / 09$ / 2016

Accepted Date: 15 / $01 / 2017$

\begin{abstract}
Financial statement analysis is the process of reviewing and analyzing a company's financial statements to make better economic decisions. When analyzing company's financial performance and calculating some ratios it is better to use EBIT (Earnings Before Interest and Taxes) information rather than net income. This is a measure of a firm's profit that includes all expenses except interest and income tax expenses. It is the difference between operating revenues and operating expenses. This is an important factor contributing to the widespread use of EBIT is the way in which it nulls the effects of the different capital structures and tax rates used by different companies. By excluding both taxes and interest expenses, the figure honest in on the company's ability to profit and thus makes for easier cross-company comparisons. EBITDA (Earnings Before Interest, Taxes, Depreciation and Amortization) is also popular among highly leveraged and capital-intensive firms that require lots of depreciation calculations, such as utilities or telecommunications companies. This is because these firms have high depreciation rates and large interest payments on debt, often leaving them with negative earnings. In this study evolution of EBIT and EBITDA disclosure in the financial data part of the annual reports of companies listed in BIST 50 (Borsa Istanbul) is investigated by comparing the year 2010 and year 2015 information.
\end{abstract}

Keywords: Financial statements, financial statement analysis, EBIT, EBITDA, BIST, Turkey

\section{Introduction}

Financial statement analysis is the process of reviewing and analyzing a company's financial statements to make better economic decisions. When analyzing company's financial performance and calculating some ratios it is better to use EBIT (Earnings_Before_Interest_and_Taxes) information rather than net income. This is a measure of a firm's profit that includes all expenses except interest and income tax expenses. EBITDA which is another data is calculated by adding back the non-cash expenses of depreciation and amortization to a firm's operating income (EBIT).

In the following section calculating EBIT and EBITDA is presented. On the third section financial ratios with EBIT and EBITDA is discussed with an example. Then the research setting is explained and findings of the research are demonstrated. In this study evolution of EBIT and EBITDA disclosure in the financial data part of the annual reports of companies listed in BIST 50 (Borsa Istanbul) is investigated by comparing the year 2010 and year 2015 information. Finally, the conclusion is presented.

\section{Calculating EBIT and EBITDA}

EBIT and EBITDA are one of the operating measures most used by analysts since net income information is not sufficient enough to declare companies real performance. Since the companies' real job is to operate business, operating income or EBIT information is much more important

\footnotetext{
${ }^{1}$ İstanbul Üniversitesi, İstanbul, Türkiye, adiloglu@istanbul.edu.tr

${ }^{2}$ İstanbul Üniversitesi, İstanbul, Türkiye, benguv@istanbul.edu.tr
} 
Adioğlu, B., Vuran, B. (2017). The importance of EBIT- EBITDA disclosure in annual reports: A comparison from Turkey. International Journal of Social Sciences and Education Research, 3(2), 397-405.

than the net income. While calculating the final line for income statement-net income- companies have to consider non-operating decisions like interest expenses (a financing decision), tax rates (a governmental decision). These expenses are related with the management and governmental decisions. While evaluating companies real performance these decisions must be excluded from the real performance measures.

In this section of the study EBIT and EBITDA calculation is presented.

Table 1. Profit and Loss Statement (Income Statement) for EBIT-EBITDA calculation

\begin{tabular}{|lr|}
\hline \multicolumn{2}{|c|}{ Star Company Profit and Loss Statement } \\
For the Year Ended December 31,2015 \\
\hline Sales & $\$ 100.000$ \\
(-) Operating Expenses & -20.000 \\
(-) Depreciation and Amortization Expense & -30.000 \\
Operating Profit (EBIT) & $\mathbf{5 0 . 0 0 0}$ \\
(-) Interest Expense & -20.000 \\
Earnings Before Taxes & 30.000 \\
(-) Taxes & -10.000 \\
Net Income & $\mathbf{2 0 . 0 0 0}$ \\
\hline
\end{tabular}

EBIT-Earnings Before Interest and Tax is the difference between operating revenues and operating expenses. This is an important factor contributing to the widespread use of EBIT is the way in which it nulls the effects of the different capital structures and tax rates used by different companies. By calculating EBIT, it nulls the effects of the different capital structures and tax rates used by different companies In the example above company's sales during the year is $\$ 100.000$ and has $\$ 20.000$ operating expenses and $\$ 30.000$ depreciation and amortization expense. During 2015 company also has $\$ 20.000$ interest expense and $\$ 10.000$ tax expense. While net income is equal to $\$ 20.000$, EBIT of this company is equal to 50.000 . The differences between two figures are interest and tax expenses. While calculating EBIT both taxes and interest expenses excluded to see the honest figure in on the company's real ability to profit. This information is so important thus makes for easier cross-company comparisons.

EBITDA-Earnings Before Interest, Taxes, Depreciation and Amortization is calculated by adding back the non-cash expenses of depreciation and amortization to a firm's operating income (EBIT). EBITDA is being used for evaluating the raw earnings power of a company since it is a measure of a company's operating performance. It is very important information of the company in order to evaluate a company's performance without having to factor in financing decisions, accounting decisions or tax environments. If a company is an industrial company depreciation expense may be huge in amount. Because of this reason especially for industrial companies EBITDA is vital information to see the companies' real profit from their real business. In table 3 also shows how EBITDA measure is important for manufacturing companies versus service companies.

In this example EBITDA is equal to EBIT plus depreciation and amortization expense, $\$ 50.000+\$ 30.000$, equals to $\$ 80.000$ Comparison of sales and three different income data and percentages are given in the table below. 
Adioğlu, B., Vuran, B. (2017). The importance of EBIT- EBITDA disclosure in annual reports: A comparison from Turkey. International Journal of Social Sciences and Education Research, 3(2), 397-405.

Table 2. Comparison of Sales, EBIT, EBITDA and Net Income

\begin{tabular}{|l|r|r|}
\hline & & \multicolumn{1}{|c|}{ Percentage of Sales } \\
\hline Sales & $\$ 100.000$ & $100 \%$ \\
\hline EBIT & $\$ 50.000$ & $50 \%$ \\
\hline EBITDA & $\$ 80.000$ & $80 \%$ \\
\hline Net Income & $\$ 20.000$ & $20 \%$ \\
\hline
\end{tabular}

As it seen from Table 2, the difference between three income concepts is obviously seen. While company is declaring $20 \%$ of net income margin, its EBIT margin is 2,5 times and EBITDA margin 4 times higher than this amount. In order to company's real ability to generate profit it is better to look EBIT or EBITDA rather than net income.

Table 3. EBIT-EBITDA measure manufacturing versus service company

\begin{tabular}{|c|c|c|c|}
\hline $\begin{array}{l}\text { Service Company A } \\
\text { Income Statement }\end{array}$ & & $\begin{array}{l}\text { Manufacturing Company B } \\
\text { Income Statement }\end{array}$ & \\
\hline Revenue & $\$ 100$ & Revenue & $\$ 100$ \\
\hline Cash Expenses & 80 & Cash Expenses & 80 \\
\hline Depreciation and Amortization & 0 & Depreciation and Amortization & 20 \\
\hline EBIT & $\$ 20$ & EBIT & \$0 \\
\hline EBITDA & $\$ 20$ & EBITDA & $\$ 20$ \\
\hline
\end{tabular}

\section{Financial Ratios with EBIT and EBITDA}

An important function of accounting is to provide performance measures, which indicate whether managers are achieving their business goals and whether the business activities are well managed. The evaluation and interpretation of financial statements and related performance measures is called financial analysis. For financial analysis to be useful, performance measures must be well aligned with the two major goals of business - profitability and liquidity. (Powers et.all, 2014)

An example is given below in order to calculate and discuss some ratios of XYZ Company. 
Adioğlu, B., Vuran, B. (2017). The importance of EBIT- EBITDA disclosure in annual reports: A comparison from Turkey. International Journal of Social Sciences and Education Research, 3(2), 397-405.

Table 4. XYZ company balance sheets summary balance sheet

\begin{tabular}{|c|c|c|c|c|c|}
\hline & \multicolumn{5}{|c|}{ Years } \\
\hline & 1 & $\mathbf{2}$ & 3 & 4 & 5 \\
\hline Cash & 14.168 & 18.416 & 20.142 & 28.856 & 10.380 \\
\hline Trading Assets & 28.144 & 24.944 & 26.524 & 36.056 & 38.716 \\
\hline Total Current Assets & 42.312 & 43.362 & 46.666 & 64.914 & 49.096 \\
\hline Property \& Equipment & 190.860 & 207.192 & 226.090 & 245.074 & 273.524 \\
\hline Less: Accumulated Depreciation & -90.338 & -108.360 & -120.566 & -136.240 & -144.572 \\
\hline Net Property \& Equipment & 100.522 & 98.832 & 105.526 & 108.834 & 128.952 \\
\hline Deposits and Other Assets & 2.148 & 3.928 & 2.944 & 2.796 & 7.246 \\
\hline Total Assets & 144.982 & 146.122 & $\mathbf{1 5 5 . 1 3 6}$ & 176.544 & 185.294 \\
\hline Accounts Payable & 7.784 & 7.148 & 7.692 & 11.900 & 9.518 \\
\hline Accrued Liabilities & 22.390 & 24.186 & 25.610 & 38.112 & 29.412 \\
\hline Other Short Term Liabilities & 2.354 & 2.396 & 124 & 7.358 & 7.276 \\
\hline Total Current Liabilities & 32.526 & 33.730 & 33.426 & 57.370 & 46.206 \\
\hline Long Term Loan & 68.144 & 66.430 & 66.154 & 58.790 & 50.816 \\
\hline Other LT Liabilities & 1448 & 1858 & 2.130 & 3.044 & 3.730 \\
\hline Total Equity & 42.864 & 44.104 & 53.424 & 57.340 & 84.540 \\
\hline Total Liabilities \& Equity & 144.982 & 146.122 & 155.136 & 176.544 & 185.294 \\
\hline
\end{tabular}

Table 5. XYZ company balance sheets summary profit and loss statement

\begin{tabular}{|c|c|c|c|c|c|}
\hline & \multicolumn{5}{|c|}{ Years } \\
\hline & 1 & 2 & 3 & 4 & 5 \\
\hline Sales & 261.968 & 249.060 & 269.602 & 304.654 & 362.346 \\
\hline Cost of Sales & 191.498 & 186.850 & 200.586 & 223.906 & 275.134 \\
\hline Gross Profit & 70.470 & 62.210 & 69.018 & 80.748 & 87.212 \\
\hline Operating Expenses & 30.512 & 32.516 & 32.346 & 34.974 & 38.582 \\
\hline Depreciation \& Amortization & 19.204 & 18.450 & 18.032 & 17.990 & 16.644 \\
\hline $\begin{array}{l}\text { Operating Profit } \\
\text { (EBIT-Earnings Before Interest and } \\
\text { Tax) }\end{array}$ & 20.754 & 11.244 & 18.640 & 27.784 & 31.986 \\
\hline Interest Expense & 3.926 & 3.516 & 3.526 & 4.168 & 6.918 \\
\hline Pre-tax Profit & 16.828 & 7.728 & 15.114 & 23.616 & 25.068 \\
\hline Tax Expense & 5.720 & 2.628 & 5.138 & 8.030 & 8.524 \\
\hline Net Profit & 11.108 & 5.100 & 9.976 & 15.586 & 16.544 \\
\hline
\end{tabular}

Balance sheets and profit or loss (income statement) of XYZ for 5 years are given above.

For the first year;

Net profit is equal to $\$ 11.108$ and

EBIT is equal to (net profit + interest expense + tax )

$\mathrm{EBIT}=\$ 11.108+\$ 3.926+\$ 5.720$

$\mathrm{EBIT}=\$ 20.754$

EBITDA is calculated by adding back the non-cash expenses of depreciation and amortization to a firm's operating income (EBIT). It is equal to (net profit + interest expense + tax + Depreciation \& Amortization) 
Adioğlu, B., Vuran, B. (2017). The importance of EBIT- EBITDA disclosure in annual reports: A comparison from Turkey. International Journal of Social Sciences and Education Research, 3(2), 397-405.

$$
\begin{aligned}
& \text { EBITDA }=\text { EBIT }+ \text { Depreciation }+ \text { Amortization } \\
& \text { EBITDA }=\$ 20.754+\$ 19.204 \\
& \text { EBITDA }=\$ 39.958
\end{aligned}
$$

While tax, interest, depreciation and amortization expense of the company is huge EBIT is approximately 2 times and EBITDA is 4 times of net profit. Also margin information are the same, net profit margin is 4,24\% whereas EBIT margin is 7,92\% and EBITDA margin 15,25\%.

Table 6. Comparison of Net Profit-EBIT-EBITDA and comparison of Net Profit-EBITEBITDA margin

\begin{tabular}{|l|r|r|r|r|r|}
\cline { 2 - 6 } \multicolumn{1}{c|}{} & \multicolumn{5}{c|}{ Years } \\
\hline Comparison of Net Profit-EBIT-EBITDA & \multicolumn{1}{|c|}{$\mathbf{1}$} & \multicolumn{1}{c|}{$\mathbf{2}$} & \multicolumn{1}{c|}{$\mathbf{3}$} & $\mathbf{5}$ \\
\hline Net Profit & 11.108 & 5.100 & 9.976 & 15.586 & 16.544 \\
EBIT & 20.754 & 11.244 & 18.640 & 27.784 & 31.986 \\
EBITDA & 39.958 & 29.694 & 36.672 & 45.774 & 48.630 \\
\hline Comparison of Net Profit-EBIT-EBITDA & $\mathbf{1}$ & $\mathbf{2}$ & $\mathbf{3}$ & 4 & $\mathbf{5}$ \\
Margin & $4,24 \%$ & $2,05 \%$ & $3,70 \%$ & $5,12 \%$ & $4,57 \%$ \\
\hline Net Profit Margin & $7,92 \%$ & $4,51 \%$ & $6,91 \%$ & $9,12 \%$ & $8,83 \%$ \\
EBIT Margin & $15,25 \%$ & $11,92 \%$ & $13,60 \%$ & $15,02 \%$ & $13,42 \%$ \\
EBITDA Margin & & & & \\
\hline
\end{tabular}

EBIT and EBITDA information and margin gives analysts to focus on the outcome of operating decisions while excluding the impacts of non-operating decisions like interest expenses, tax rates or large non-cash items like depreciation and amortization. To analyze companies' real profit from its own business it is better to look EBIT, if this is a industrial company because of the huge depreciation and amortization expenses EBITDA information will be more suitable to consider profitability. In this XYZ Company it will be more suitable to give decisions about company's profitability by looking EBIT and also EBITDA measure. In table 7 some performance measures of XYZ company is also given.

Table 7. Performance measures

\begin{tabular}{|l|r|r|r|r|r|}
\cline { 2 - 6 } \multicolumn{1}{c|}{} & \multicolumn{5}{c|}{ Years } \\
\hline Performance Measures & $\mathbf{1}$ & \multicolumn{1}{c|}{$\mathbf{2}$} & \multicolumn{1}{c|}{$\mathbf{3}$} & \multicolumn{1}{c|}{$\mathbf{5}$} \\
\hline Sales Growth & $14,40 \%$ & $-4,93 \%$ & $8,25 \%$ & $13,00 \%$ & $18,94 \%$ \\
\hline EBIT Growth & $50,30 \%$ & $-45,80 \%$ & $65,80 \%$ & $49,10 \%$ & $15,10 \%$ \\
\hline Net Profit Growth & $-21,40 \%$ & $-54,09 \%$ & $95,61 \%$ & $56,26 \%$ & $6,13 \%$ \\
\hline Return on Equity(ROE) & $25,90 \%$ & $11,73 \%$ & $20,46 \%$ & $28,14 \%$ & $23,32 \%$ \\
\hline $\begin{array}{l}\text { Return on Investments } \\
\text { (ROI) (Net Profit) }\end{array}$ & $7,66 \%$ & $3,50 \%$ & $6,62 \%$ & $9,40 \%$ & $9,14 \%$ \\
\hline $\begin{array}{l}\text { Return on Investments } \\
\text { (ROI) -(EBIT) }\end{array}$ & $14,31 \%$ & $7,73 \%$ & $12,37 \%$ & $16,75 \%$ & $17,68 \%$ \\
\hline
\end{tabular}

The return on equity (ROE) is the percentage of net income that is available to the owner. It is determined by dividing the net income by owners 'equity to give the return on owners' fund. (Weil and Noi, 2001) 
Adioğlu, B., Vuran, B. (2017). The importance of EBIT- EBITDA disclosure in annual reports: A comparison from Turkey. International Journal of Social Sciences and Education Research, 3(2), 397-405.

The Formula is:

Return on Equity = Profit after tax / Average Shareholders' Equity

Return on equity gives the information of how much the shareholders earned from their investment in the company.

Return on Investments ${ }^{1}$ (ROI or ROA): ROI or ROA relates the profit to the size of the investment used to generate it. (Friedlob and Plewa, 1983) This ratio indicates how profitable a company is relative to its total assets. The return on investments or assets (ROA) ratio illustrates how well management is employing the company's total assets to make a profit. On order to get more efficient information it will be better to consider EBIT to see the real performance of the management. So that the ROI or ROA ratio must be calculated by comparing operating profit (EBIT) to average total assets in order to when comparing similar companies across a single industry, or companies operating in different tax amounts.

The Formula is:

Return on Assets $=$ EBIT $/$ Average Total Assets

Some investment analysts use the net income figure instead of the operating income figure when calculating the ROI ratio. As it seen on the table 7 the difference between the ROI is seen.(In the first calculation net income is divided by average total assets while EBIT is divided by average total assets in the second ROI calculation) Since the EBIT shows the real information how the management is employing the company's total assets, ROI calculated by using EBIT gives more clear information about companies profitability.

\section{Research setting, methodology and findings}

In order to monitor the evolution of reporting on EBIT and EBITDA relevant information in the 2010 and 2015 annual reports of the ISE-50 Industrial companies are were examined. The sample selection starts with the entire population of BIST 50 companies because financial statements have different aspects 8 financial company excluded from the study, 42 industrial firms are included in the study. Since the annual reports of two of these 42 companies cannot be obtained, the research was conducted on the annual reports of the remaining 40 companies that published their annual reports in their websites.

The most 5 important data are investigated in the financial highlight sections of the annual reports. These are sales, investments, net income, EBIT and EBITDA measure. After analyzing financial highlight sections of the 40 annual reports disclosure levels and disclosure percentages are given in Table 8 .

\footnotetext{
${ }^{1}$ Total assets or fixed assets can be defined as investment in this ratio.
} 
Adioğlu, B., Vuran, B. (2017). The importance of EBIT- EBITDA disclosure in annual reports: A comparison from Turkey. International Journal of Social Sciences and Education Research, 3(2), 397-405.

Table 8. Annual reports disclosure levels and disclosure percentages

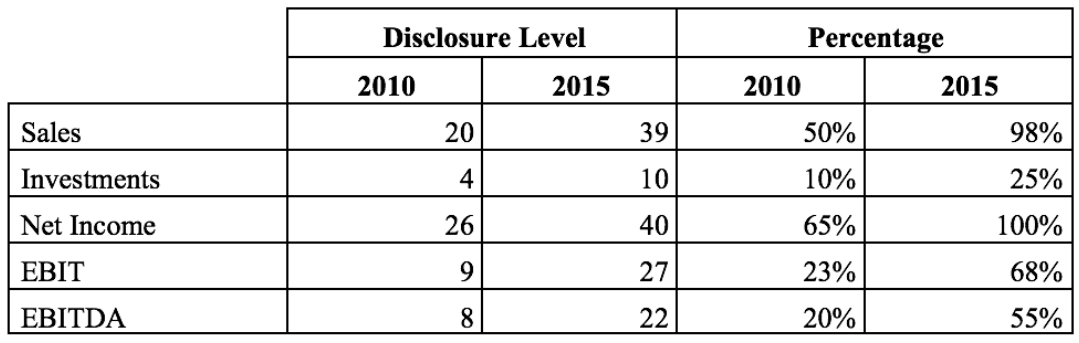

Compared to 2010 there has been a noticeable improvement in companies' reporting their financial information on a separate highlight section. In 201598 percent of companies disclose sales, 25 percent of companies disclose investments, 100 percent of companies disclose net income, 68 percent of companies disclose EBIT and 55 percent of companies disclose EBITDA information. Figure 1 also shows this improvement of disclosure of these selected data by years

Figure 1. Disclosure of these selected data by years

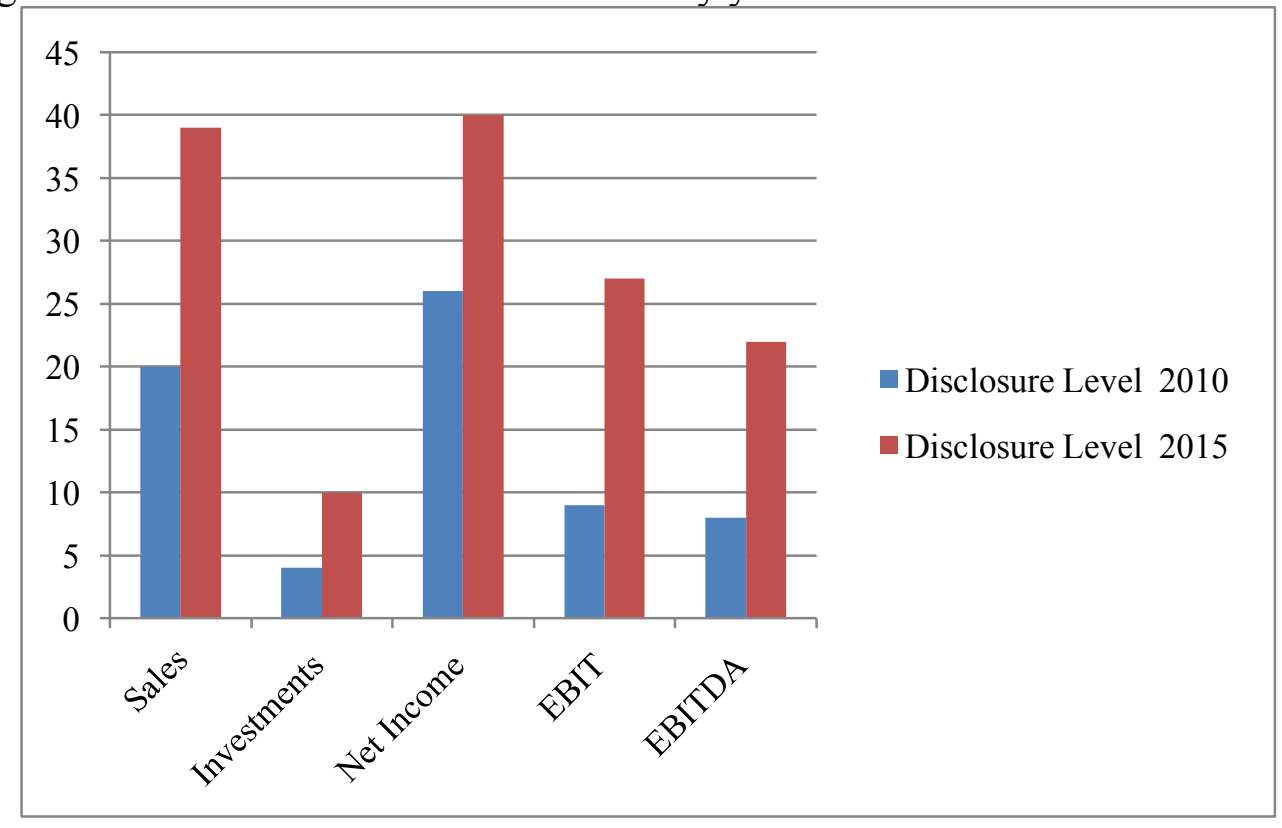

In addition to analyzing disclosure of these data in annual reports is also analyzed whether the company showed this information in graphics and calculated ratios by using these data.

Table 9. Graphics and ratios

\begin{tabular}{|l|c|c|}
\cline { 2 - 3 } \multicolumn{1}{c|}{} & $\mathbf{2 0 1 0}$ & $\mathbf{2 0 1 5}$ \\
\hline Graphics & 12 & 26 \\
\hline Ratios & 11 & 28 \\
\hline
\end{tabular}

While 12 of 40 companies in 2010 and 26 of 40 companies in 2015 are showing these data in graphics, 11 of them in 2010 and 28 of them in 2010 calculated ratios by using these important measures. Figure 2 also represents this information. 
Adioğlu, B., Vuran, B. (2017). The importance of EBIT- EBITDA disclosure in annual reports: A comparison from Turkey. International Journal of Social Sciences and Education Research, 3(2), 397-405.

Figure 2. Graphics and ratios information

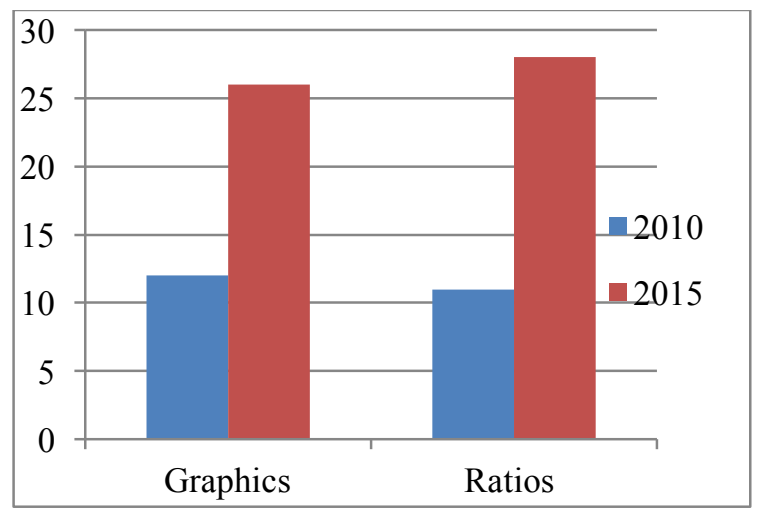

In table 10 disclosure levels and percentages of net income margin, EBIT margin, EBITDA margin, return on equity (ROE), return on investments or assets (ROI) is given by comparing 2010 and 2015.

Table 10. Disclosure levels and percentages of net income margin, EBIT margin, EBITDA margin

\begin{tabular}{|l|rr|r|rr|r|}
\cline { 2 - 6 } \multicolumn{1}{c|}{} & \multicolumn{3}{c|}{ Disclosure Level } & \multicolumn{3}{c|}{ Percentage } \\
\cline { 2 - 7 } \multicolumn{1}{c|}{} & $\mathbf{2 0 1 0}$ & $\mathbf{2 0 1 5}$ & $\mathbf{2 0 1 0}$ & $\mathbf{2 0 1 5}$ \\
\hline Net Income Margin & & 18 & 30 & $45 \%$ & $75 \%$ \\
\hline EBIT Margin & & 9 & 15 & $23 \%$ & $38 \%$ \\
\hline EBITDA Margin & & 4 & 10 & $10 \%$ & $25 \%$ \\
\hline ROE & & 5 & 12 & $13 \%$ & $30 \%$ \\
\hline ROI (ROA) & & 6 & 14 & $15 \%$ & $35 \%$ \\
\hline
\end{tabular}

Although EBIT and EBITDA information is very important for industrial companies disclosure level of these margins are too low. According to these findings in annual reports, companies are not disclosing their performance sufficient enough to declare their real performance. They still find enough to declare only their net profit as a measure of performance. Figure 3 also shows evolution of these data in years.

Figure 3. Evolution of EBIT and EBITDA data

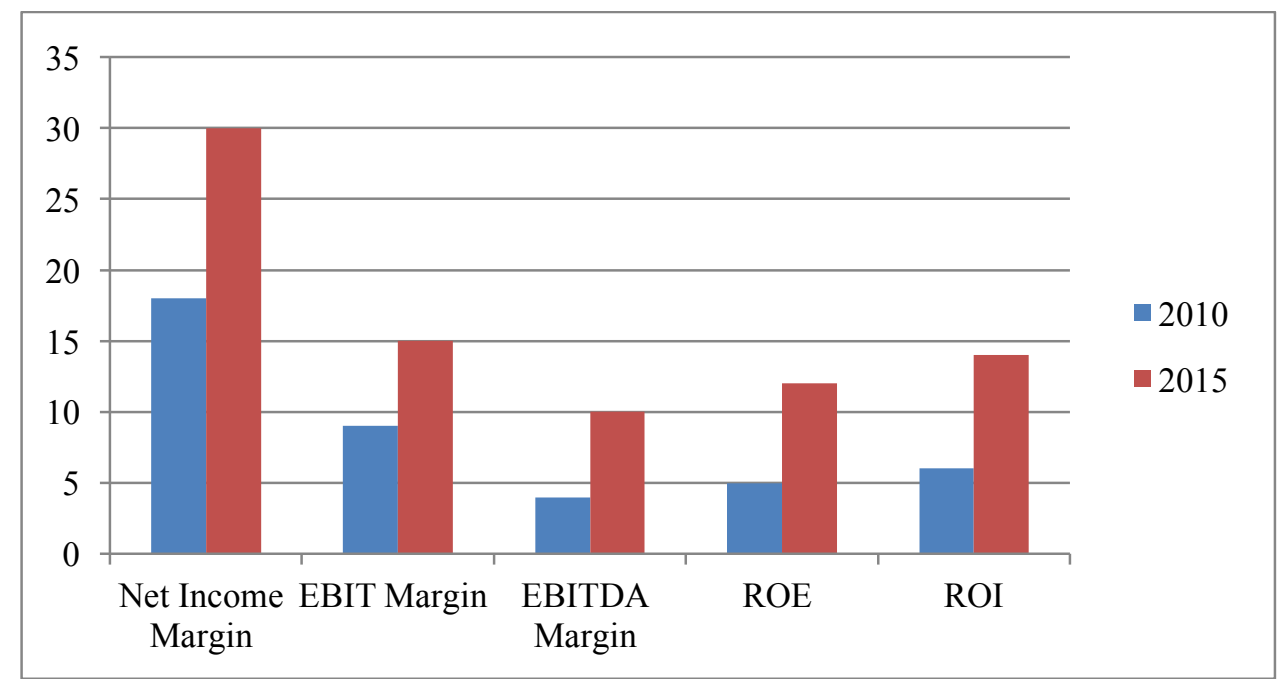


Adioğlu, B., Vuran, B. (2017). The importance of EBIT- EBITDA disclosure in annual reports: A comparison from Turkey. International Journal of Social Sciences and Education Research, 3(2), 397-405.

\section{Conclusion}

Net Profit After Tax is an important data income statement. But, tax depends on state regulations and interest expense is a function of leverage of the company. So the real signal for operating activities for a company is EBIT. Especially for manufacturing companies, since depreciation and amortization can be huge amounts, in financial analysis, it is better to calculate EBIT and EBITDA in order to report the real performance. EBITDA is calculated using the company's income statement. It is a measure of a company's operating performance. Essentially, it's a way to evaluate a company's performance without having to factor in financing decisions, accounting decisions or tax environments. It is not included as a line item, but can be easily derived by using the other line items that must be reported on an income statement. By excluding the non-operating effects that changes from one company to other EBIT and EBITDA allows investors to focus on operating profitability as measure of performance. Therefore, when analyzing an industrial firm EBITDA is the best measure for cross-company comparisons in conjunction with other factors such as capital expenditures, changes in working capital requirements, debt payments and net income. The study highlights that the companies' attitude towards disclosing these information is encouraging but still not sufficient. For further studies this research can be done to see the disclosure level of these information in order to compare the improvements by years.

\section{References}

Borsa Istanbul (2016). http://www.borsaistanbul.com/

Friedlob, G. T., Plewa Jr., F. J. (1983). Understanding return on investments, Wiley-Blackwell.

Powers, M., Needles, B, Crosson S., (2014) Principles of accounting, South-Western Cengage Learning.

Weil S.H, Noi F.,(2001). Introductory accounting skills: for financial and management accounting students, Juta and Company Ltd. 